\section{Buffer Overrun Madness}

Rodney Bates' excellent article, "Buffer Overrun Madness" (May 2004), grows ever more timely. Unruly languages such as $\mathrm{C}$ and its descendants require increasingly disciplined programmers.

$$
\text { Robert Cody, Alexandria, Virginia }
$$

The Morris worm struck 15 years ago, and though experienced $\mathrm{C}$ programmers are aware of the problems with these routines, they continue to use them.

Plus, $\mathrm{C}$ has evolved into $\mathrm{C}++$, which has not improved safety. In fact, millions of lines of unsafe code have been written.

$$
\text { Lawrence C. Paulson, Cambridge, England }
$$

RODNEY BATES RESPONDS: Since, as Paulson emphasizes, the industry has yet to hear this message, it bears continual repetition.

Rodney Bates reminds us of some important failings of both programming languages and programmers. Unfortunately, he treats $\mathrm{C}++$ as if it were $\mathrm{C}$, rather than as a considerably different language that lets you write very robust code.

Todd Greer, Austin, Texas RODNEY BATES RESPONDS: C++ has done nothing to plug the type safety holes in C's arrays, or any other part of its type system. Yes, C++ adds some safer alternatives, but these help only where they are used.

\section{Open Source: All Grown Up?}

Programmers might underestimate the complexities involved with a company's move to open source, so thanks for the thoughtful articles (May 2004) from what I would call a "positivistic" perspective, explaining the challenges ahead.

Jordan Hubbard's "Open Source to the Core" described the importance of internal buy-in and understanding by internal departments. Jay Michaelson's legal perspective in "There's No Such Thing as a Free (Software) Lunch" clarified contract and copyright law. David Ascher's "Is OS Right for You?" explained how process challenges can be part of a move toward open source.

\section{To submit a}

letter, E-MAIL US AT

FEEDBACK@ACMQUEUE.COM

And Josh Coates' "A Bigot by Any Other Name" had some good points.

If $A C M$ Queue keeps publishing issues of the quality, depth, and relevance of this one, I may have to renew my subscription!

$$
\text { Daniel Meyer, Muncie, Indiana }
$$

\section{When Is Free Really Free?}

After reading Jay Michaelson's “There's No Such Thing as a Free (Software) Lunch" (May 2004), which discusses various open source licenses, I have to ask if we're all "smoking crack" —as Linus Torvalds put it. Did we forget the copy part of copyright?

On what planet should the owner of the copyright to the kernel have any copyright claim over device drivers that don't copy kernels or other source modules at all? It doesn't do what they do. It's not an editorial revision, annotation, elaboration, or modification. It's not a "derivative work."

$$
\text { Gary Hewitt, Silver Spring, Maryland }
$$

JAY MICHAELSON RESPONDS: Although copyright law can seem out of control at times, it is specifically referenced by the GPL (GNU General Public License). A derivative work under one regime is likely a derivative work by another.

Since the open source issue of ACM Queue was published, a German court prohibited the distribution of a product until the company making it complied with the GPL.

\section{It's Not Cool to be a Bigot}

Josh Coates shared some valid ideas in his Curmudgeon rant, "A Bigot by Any Other Name" (May 2004), but to suggest Excel is an "incredibly excellent piece of software" makes me wonder about his standards.

$$
\text { John C. Nash, Ottawa, Ontario, Canada }
$$

JOSH COATES RESPONDS: Excel is an incredible software application and I challenge anyone to point out a "better" spreadsheet application. Do Excel and other spreadsheet tools need to improve, however? You betcha.

We edit letters for content, style, and length. $Q$ 